\title{
Methyl cinnamate increases cell vulnerability to oxidative stress induced by hydrogen peroxide in rat thymocytes
}

\author{
Hiromitsu Tsuzuki ${ }^{1, *}$, Shota Inoue ${ }^{1, *}$, Daiki Kobayashi ${ }^{1, *}$, Gantulga Uuganbaatar ${ }^{1, *}$ \\ Kaori Kanemaru², Kumio Yokoigawa² and Yasuo Oyama² \\ ${ }^{1}$ Graduate School of Integrated Arts and Sciences, Tokushima University, Tokushima 770-8502, Japan \\ ${ }^{2}$ Faculty of Bioscience and Bioindustry, Tokushima University, Tokushima 770-8513, Japan
}

(Received April 16, 2016; Accepted April 22, 2016)

\begin{abstract}
Methyl cinnamate (MC) and essential oils containing MC possess beneficial antimicrobial, antifungal, and insecticidal effects, among others. Such effects are related to the biocidal action of MC. The antioxidant activity of MC has also been reported elsewhere. It has been suggested that MC may be cytotoxic to cells exposed to oxidative stress. To test this possibility, the effect of MC on rat thymocytes was examined while the cells were subjected to oxidative stress induced by hydrogen peroxide $\left(\mathrm{H}_{2} \mathrm{O}_{2}\right)$. Flow cytometric techniques with appropriate fluorescent probes were used for quantification. MC increased cell vulnerability to oxidative stress via acceleration of the cell death process and/or potentiation of oxidative stress. The use of MC is widespread because of its beneficial actions, and thus further attention should be paid to whether MC is effective under oxidative stress.
\end{abstract}

Key words: Methyl cinnamate, Hydrogen peroxide, Cytotoxicity, Lymphocytes, Oxidative stress

\section{INTRODUCTION}

Methyl cinnamate (MC) is a methyl ester of cinnamate. It is one of the major components of essential oils extracted from herbal plants (Politeo et al., 2007; Gilles et al., 2010). MC and essential oils containing MC possess antimicrobial, antifungal, insecticidal, and antioxidant effects (Peterson et al., 2000; El-Massry et al., 2002; Peretto et al., 2014; Vieira et al., 2014). The cytotoxic action of essential oils containing MC on tumor cells has been reported (Ferraz et al., 2013; Shirazi et al., 2014). All the effects of MC, except for its antioxidant activity, are related to its biocidal action. Therefore, it is suggested that MC could exert cytotoxic action on mammalian cells exposed to oxidative stress, despite being an antioxidant. In the present study, to test this possibility, the effect of MC on rat thymocytes was examined while the cells were subjected to oxidative stress induced by hydrogen peroxide $\left(\mathrm{H}_{2} \mathrm{O}_{2}\right)$. Flow cytometric techniques with appropriate fluorescent probes were used for quantification. The use of MC is widespread; it can be used as a food flavoring, cosmetic fragrance, and for management of obesity (Bhatia et al., 2007; Chen et al., 2012). Therefore, this study may provide insights into the toxicological profile of $\mathrm{MC}$ for its safe use.

\section{MATERIALS AND METHODS}

\section{Cell preparation}

This study was approved by the Committee for Animal Experiments of Tokushima University, Tokushima, Japan (No. 14124). The cell suspension was prepared as previously reported (Chikahisa et al., 1996). In brief, the thymus glands dissected from ether-anesthetized rats were sliced under cold conditions. The slices were triturated in Tyrode's solution to dissociate the thymocytes. The cell suspension was incubated at $36-37^{\circ} \mathrm{C}$ for $1 \mathrm{hr}$ before the experiment.

\section{Chemicals}

MC was purchased from Tokyo Chemical Industry Co., Ltd. (Tokyo, Japan). Annexin V-FITC, propidium iodide, and 5-chloromethylfluorescein diacetate (5CMF-DA) were obtained from Molecular Probes Inc., Invitrogen (Eugene, OR, USA). Other chemicals were obtained from Wako Pure Chemicals (Osaka, Japan) unless otherwise mentioned.

Correspondence: Yasuo Oyama (E-mail: oyamay@tokushima-u.ac.jp)

*These authors equally contributed to this work. 


\section{Measurements of cellular parameters}

To assess cell lethality (the population of dead cells), propidium iodide was added to the cell suspension to a final concentration of $5 \mu \mathrm{M}$. Exposure of phosphatidylserine on the outer surface of cell membranes is a marker of the early stages of apoptosis, and was detected using $10 \mu \mathrm{L} / \mathrm{mL}$ annexin V-FITC (Koopman et al., 1994). 5-CMF-DA at a concentration of $1 \mu \mathrm{M}$ was used to monitor changes in cellular content of non-protein thiols, such as glutathione (Chikahisa et al., 1996). The excitation wavelength for the fluorescent probes was $488 \mathrm{nM}$. Fluorescence of FITC and 5-CMF was detected at $530 \pm$ $20 \mathrm{~nm}$. Propidium fluorescence was detected at $600 \pm$ $20 \mathrm{~nm}$. 5-CMF fluorescence was monitored only for living cells that did not exhibit propidium fluorescence.

\section{Statistical analysis}

Statistical analyses were performed by ANOVA with post-doc Tukey's multivariate analysis. P-values of less than 0.05 were considered significant. Results (including columns and bars in figures) are expressed as the mean and standard deviation of four samples.

\section{RESULTS AND DISCUSSION}

\section{Changes in cell lethality by $\mathrm{MC}$ and $\mathrm{H}_{2} \mathrm{O}_{2}$}

As shown in Fig. 1A, the incubation of thymocytes with $300 \mu \mathrm{M}$ MC for $3 \mathrm{hr}$ did not increase the population of cells exhibiting propidium fluorescence, which indicates that $300 \mu \mathrm{M} \mathrm{MC}$ did not increase the population of dead cells. However, incubation with $300 \mu \mathrm{M}$ $\mathrm{H}_{2} \mathrm{O}_{2}$ significantly increased the population of dead cells (Fig. 1A). Thus, $300 \mu \mathrm{M} \mathrm{H}_{2} \mathrm{O}_{2}$ is suggested to be cytotoxic to rat thymocytes. The simultaneous application of 300 $\mu \mathrm{M} \mathrm{H}_{2} \mathrm{O}_{2}$ and $300 \mu \mathrm{M} \mathrm{MC}$ further increased the population of dead cells. This further increase was also observed in the case of $100 \mu \mathrm{M} \mathrm{MC}$, but not with $30 \mu \mathrm{M} \mathrm{MC}$. We thus concluded that $100-300 \mu \mathrm{M}$ MC potentiates the cytotoxicity of $300 \mu \mathrm{M} \mathrm{H}_{2} \mathrm{O}_{2}$ (Fig. 1B).

The incubation of thymocytes with $100-300 \mu \mathrm{M} \mathrm{H}_{2} \mathrm{O}_{2}$ for $3 \mathrm{hr}$ significantly increased the population of dead cells. The simultaneous application of $300 \mu \mathrm{M}$ MC with 100-300 $\mu \mathrm{M} \mathrm{H}_{2} \mathrm{O}_{2}$ further induced an increase in the dead cell population (Fig. 1C). The difference in cell lethality between the control group and the group of cells simultaneously treated with $30 \mu \mathrm{M} \mathrm{H}_{2} \mathrm{O}_{2}$ and $300 \mu \mathrm{M} \mathrm{MC}$ was statistically significant. There was no statistically significant difference between the group of cells treated with $30 \mu \mathrm{M} \mathrm{H}_{2} \mathrm{O}_{2}$ alone and the group of cells treated with $30 \mu \mathrm{M} \mathrm{H} \mathrm{H}_{2} \mathrm{O}_{2}$ and $300 \mu \mathrm{M} \mathrm{MC}$. It is unlikely that MC potentiates the action of $30 \mu \mathrm{M} \mathrm{H}_{2} \mathrm{O}_{2}$.

\section{Effects of $\mathrm{MC}, \mathrm{H}_{2} \mathrm{O}_{2}$, and their combination on process of cell death}

The effect of $300 \mu \mathrm{M} \mathrm{MC}$ on the process of cell death induced by $300 \mu \mathrm{M} \mathrm{H}_{2} \mathrm{O}_{2}$ was examined using propidium iodide and annexin V-FITC. The effect was examined at $2 \mathrm{hr}$ after drug application. The populations of intact living cells (exhibiting neither propidium fluorescence nor FITC fluorescence), annexin V-positive living cells (FITC fluorescence but not propidium fluorescence), and dead cells (propidium fluorescence) were not altered by treatment with $300 \mu \mathrm{M}$ MC (Fig. 2A). However, the incubation of thymocytes with $300 \mu \mathrm{M} \mathrm{H}_{2} \mathrm{O}_{2}$ significantly decreased the population of intact living cells and increased those of annexin V-positive living cells and dead cells. The combination of $\mathrm{MC}$ and $\mathrm{H}_{2} \mathrm{O}_{2}$ further increased the population of dead cells, as seen in the decrease of the population of annexin V-positive living cells. MC is suggested to accelerate the transition from annexin $\mathrm{V}$-positive living cells to dead cells.

\section{Changes in cellular content of nonprotein thiols by $\mathrm{MC}, \mathrm{H}_{2} \mathrm{O}_{2}$, and their combination}

To determine if $\mathrm{MC}$ augments the oxidative stress induced by $\mathrm{H}_{2} \mathrm{O}_{2}$, the effects of $\mathrm{MC}, \mathrm{H}_{2} \mathrm{O}_{2}$, and a combination of the two on the cellular content of nonprotein thiols, mainly glutathione, were examined using 5CMF fluorescence (Chikahisa et al., 1996). The incubation of thymocytes with 300-100 $\mu \mathrm{M}$ MC for $3 \mathrm{hr}$ did not change the intensity of 5CMF fluorescence. $\mathrm{MC}$ at $300 \mu \mathrm{M}$ slightly attenuated 5CMF fluorescence (Fig. 2B). This slight attenuation was statistically significant. $\mathrm{H}_{2} \mathrm{O}_{2}$ at $30 \mu \mathrm{M}$ increased the intensity of 5CMF fluorescence, while a more significant reduction of 5CMF fluorescence was observed at $100-300 \mu \mathrm{M} \mathrm{H}_{2} \mathrm{O}_{2}$. In previous studies (Kinazaki et al., 2011; Fukunaga et al., 2013), we suggested that intracellular $\mathrm{Zn}^{2+}$ release in response to oxidative stress is a trigger for the restoration of the cellular content of nonprotein thiols that is decreased by oxidative stress. $\mathrm{H}_{2} \mathrm{O}_{2}$ at higher concentrations predominantly reduces cellular thiol content. Simultaneous application of either 30 or $100 \mu \mathrm{M} \mathrm{H}_{2} \mathrm{O}_{2}$ and $300 \mu \mathrm{M} \mathrm{MC}$ greatly reduced the intensity of 5CMF fluorescence (Fig. 2C). These results suggest that the combination $\mathrm{MC}$ and $\mathrm{H}_{2} \mathrm{O}_{2}$ reduces the cellular content of nonprotein thiols, although $\mathrm{H}_{2} \mathrm{O}_{2}$ at low concentrations tends to elevate cellular thiol levels. It is likely that $\mathrm{MC}$ potentiates $\mathrm{H}_{2} \mathrm{O}_{2}$-induced oxidative stress with influential consequences.

Taken together, $\mathrm{MC}$ increases the vulnerability of rat thymocytes to oxidative stress induced by $\mathrm{H}_{2} \mathrm{O}_{2}$, and either accelerates the cell death process induced by $\mathrm{H}_{2} \mathrm{O}_{2}$ and/or potentiates $\mathrm{H}_{2} \mathrm{O}_{2}$-induced oxidative stress. The use 
(A)

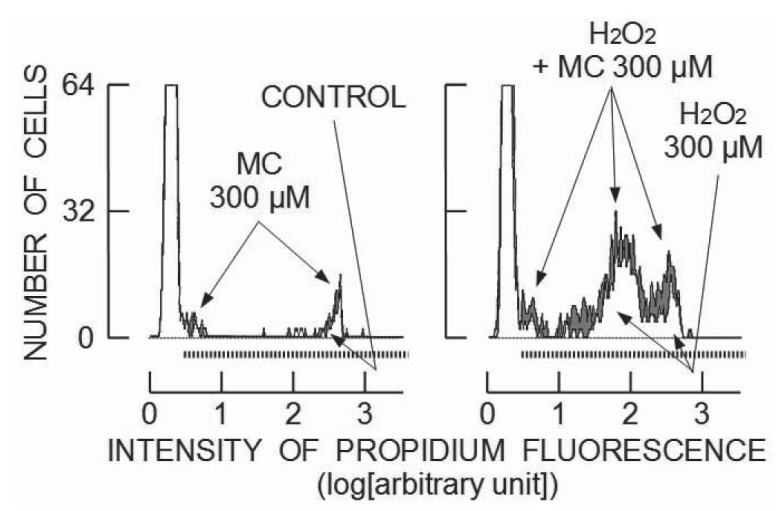

(B)

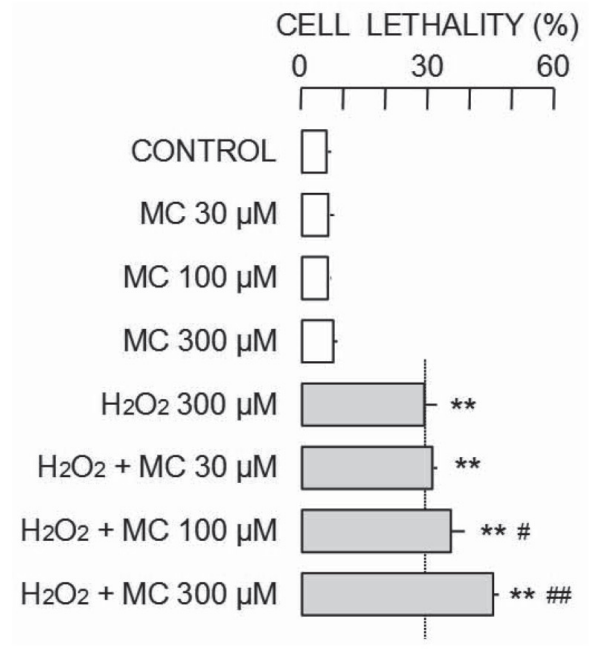

(C)

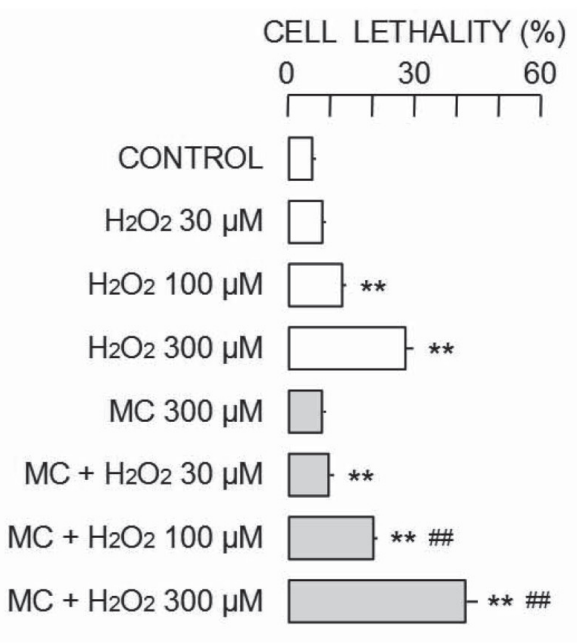

Fig. 1. Changes in population of cells exhibiting propidium fluorescence (cell lethality) by $\mathrm{MC}, \mathrm{H}_{2} \mathrm{O}_{2}$, and the combination of the two. (A) Changes in histograms of propidium fluorescence. Each histogram was constructed with 2,000 cells. Effects were examined at $3 \mathrm{hr}$ after drug application. (B) Changes in cell lethality after application of $300 \mu \mathrm{M} \mathrm{H}_{2} \mathrm{O}_{2}$ and 30-300 $\mu \mathrm{M} \mathrm{MC}$. Asterisk $(* *)$ indicates a significant difference between the control group (CONTROL) and test groups. Symbols (\#, \#\#) show a significant difference $(\mathrm{P}<0.05, \mathrm{P}<0.01)$ between the group of cells treated with $300 \mu \mathrm{M} \mathrm{H}_{2} \mathrm{O}_{2}$ and the group of cells simultaneously treated with $\mathrm{H}_{2} \mathrm{O}_{2}$ and 30-300 $\mu$ M MC. (C) Changes in cell lethality after application of 30-300 $\mu \mathrm{M}$ $\mathrm{H}_{2} \mathrm{O}_{2}$ and $300 \mu \mathrm{M}$ MC. Asterisk (**) indicates a significant difference $(\mathrm{P}<0.01)$ between the control group (CONTROL) and test groups. Symbol $(\# \#)$ shows a significant difference $(\mathrm{P}<0.01)$ between the group of cells treated with $30-300 \mu \mathrm{M}$ $\mathrm{H}_{2} \mathrm{O}_{2}$ and the group of cells simultaneously treated with $\mathrm{H}_{2} \mathrm{O}_{2}$ and $300 \mu \mathrm{M} \mathrm{MC}$.

of MC is widespread owing to its many beneficial effects, and thus further attention should be paid to whether MC is effective under oxidative stress.

\section{ACKNOWLEDGMENTS}

This study was supported by the Grant-in-Aid for
Scientific Research (C26340039) from the Japanese Society for the Promotion of Science (Tokyo, Japan).

Conflict of interest---- The authors declare that there is no conflict of interest. 
H. Tsuzuki et al.

\section{(A)}

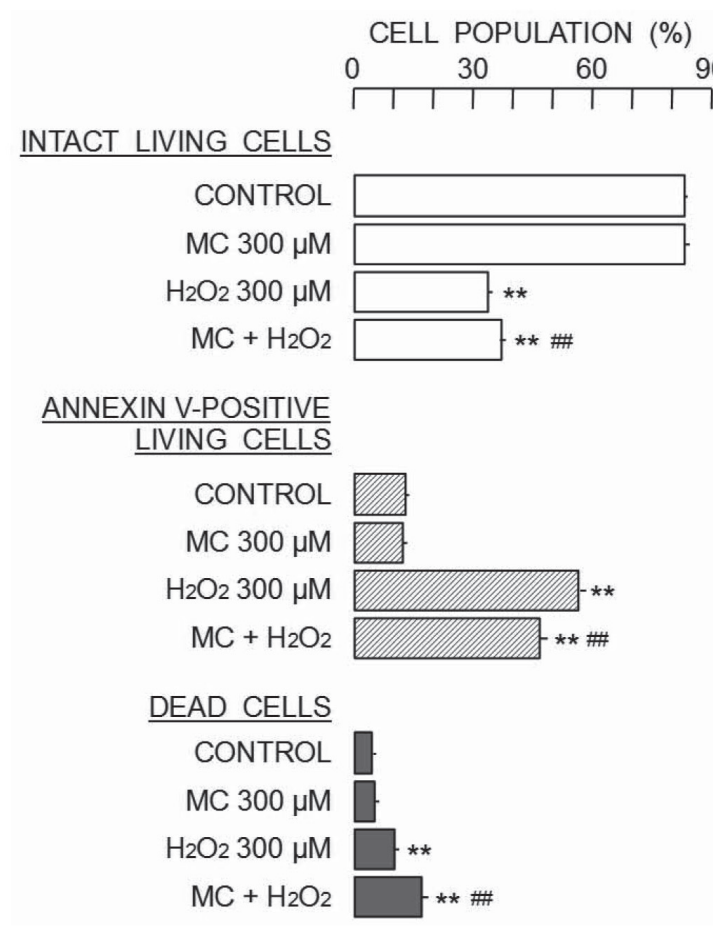

(B)

(C)
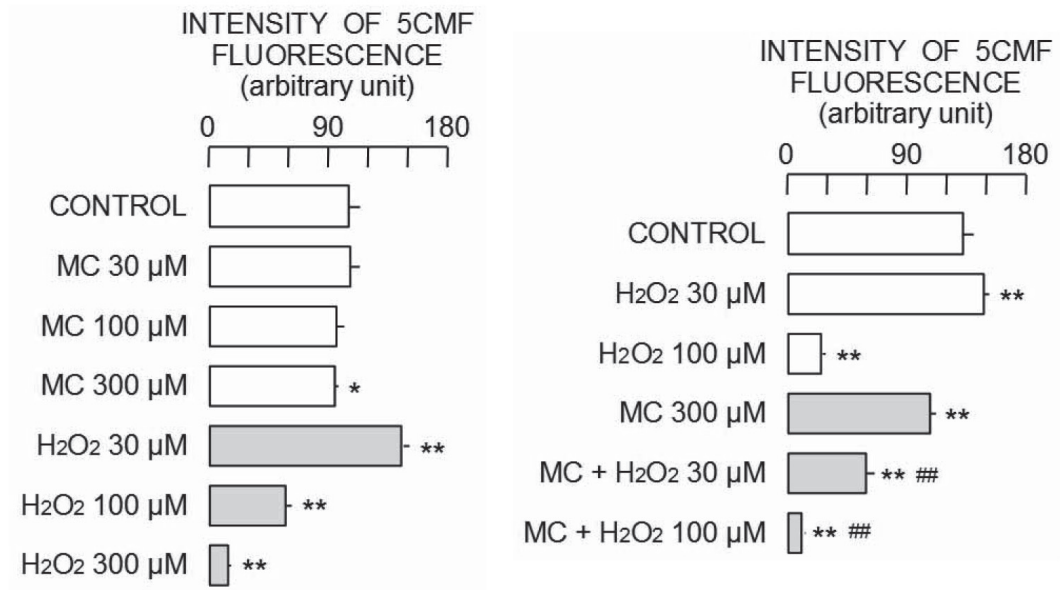

Fig. 2. Changes in cellular parameters by $\mathrm{MC}, \mathrm{H}_{2} \mathrm{O}_{2}$, and the combination of the two. (A) Changes in cell population classified by propidium iodide and annexin V-FITC. The cells exhibiting neither propidium fluorescence nor FITC fluorescence were defined as intact living cells (INTACT LIVING CELLS). The cells exhibiting FITC fluorescence but not propidium fluorescence were the living cells positive to annexin V (ANNEXIN V-POSITIVE LIVING CELLS). The dead cells (DEAD CELLS) were stained with propidium, and exhibited propidium fluorescence. Asterisk $(* *)$ indicates a significant difference $(\mathrm{P}<0.01)$ between the control group $(\mathrm{CONTROL})$ and test groups. Symbol (\#\#) shows a significant difference $(\mathrm{P}<0.01)$ between the group of cells treated with $\mathrm{H}_{2} \mathrm{O}_{2}$ alone and that with $\mathrm{H}_{2} \mathrm{O}_{2}$ and MC. (B) Changes in 5CMF fluorescence by 30$300 \mu \mathrm{M} \mathrm{MC}$ or $30-300 \mu \mathrm{M} \mathrm{H}_{2} \mathrm{O}_{2}$. Asterisks $(*, * *)$ indicate a significant difference $(\mathrm{P}<0.05, \mathrm{P}<0.01)$ between the control group (CONTROL) and test groups. (C) Changes in 5CMF fluorescence by the combination of $\mathrm{MC}$ and $\mathrm{H}_{2} \mathrm{O}_{2}$. Asterisk (**) indicates a significant difference $(\mathrm{P}<0.01)$ between the control group $(\mathrm{CONTROL})$ and test groups. Symbol (\#\#) shows a significant difference $(\mathrm{P}<0.01)$ between the group of cells treated with $\mathrm{MC}$ alone and with $\mathrm{MC}$ and $\mathrm{H}_{2} \mathrm{O}_{2}$ together. 
Methyl cinnamate and oxidative stress

\section{REFERENCES}

Bhatia, S.P., Wellington, G.A., Cocchiara, J., Lalko, J., Letizia, C.S. and Api, A.M. (2007): Fragrance material review on methyl cinnamate. Food Chem. Toxicol., 45, S113-S119.

Chen, Y.Y., Lee, M.H., Hsu, C.C., Wei, C.L. and Tsai, Y.C. (2012): Methyl cinnamate inhibits adipocyte differentiation via activation of the CaMKK2-AMPK pathway in 3T3-L1 preadipocytes. J. Agric. Food Chem., 60, 955-963.

Chikahisa, L., Oyama, Y., Okazaki, E. and Noda, K. (1996): Fluorescent estimation of $\mathrm{H}_{2} \mathrm{O}_{2}$-induced changes in cell viability and cellular nonprotein thiol level of dissociated rat thymocytes. Jpn. J. Pharmacol., 71, 299-305.

El-Massry, K.F., El-Ghorab, A.H. and Farouk, A. (2002): Antioxidant activity and volatile components of Egyptian Artemisia judaica L. Food Chem., 79, 331-336.

Ferraz, R.P., Bomfim, D.S., Carvalho, N.C., Soares, M.B., da Silva, T.B., Machado, W.J., Prata, A.P., Costa, E.V., Moraes, V.R., Nogueira, P.C. and Bezerra, D.P. (2013): Cytotoxic effect of leaf essential oil of Lippia gracilis Schauer (Verbenaceae). Phytomedicine, 20, 615-621.

Fukunaga, E., Kanbara, Y. and Oyama, Y. (2013): Role of $\mathrm{Zn}^{2+}$ in restoration of nonprotein thiol content in the cells under chemical stress induced by triclocarban. Nat. Sci. Res., 27, 1-5.

Gilles, M., Zhao, J., An, M. and Agboola, S. (2010): Chemical composition and antimicrobial properties of essential oils of three Australian Eucalyptus species. Food Chem., 119, 731-737.

Kinazaki, A., Chen, H., Koizumi, K., Kawanai, T., Oyama, T.M.,
Satoh, M., Ishida, S., Okano, Y. and Oyama, Y. (2011): Putative role of intracellular $\mathrm{Zn}^{2+}$ release during oxidative stress: a trigger to restore cellular thiol content that is decreased by oxidative stress. J. Physiol. Sci., 61, 403-409.

Koopman, G., Reutelingsperger, C.P., Kuijten, G.A., Keehnen, R.M., Pals, S.T. and van Oers, M.H. (1994): Annexin V for flow cytometric detection of phosphatidylserine expression on B cells undergoing apoptosis. Blood, 84, 1415-1420.

Peretto, G., Du, W.X., Avena-Bustillos, R.J., Berrios, J.D.J., Sambo, P. and McHugh, T.H. (2014): Optimization of antimicrobial and physical properties of alginate coatings containing carvacrol and methyl cinnamate for strawberry application. J. Agric. Food Chem., 62, 984-990.

Peterson, C.J., Tsao, R., Eggler, A.L. and Coats, J.R. (2000): Insecticidal activity of cyanohydrin and monoterpenoid compounds. Molecules, 5, 648-654.

Politeo, O., Jukic, M. and Milos, M. (2007): Chemical composition and antioxidant capacity of free volatile aglycones from basil (Ocimum basilicum L.) compared with its essential oil. Food Chem., 101, 379-385.

Shirazi, M.T., Gholami, H., Kavoosi, G., Rowshan, V. and Tafsiry, A. (2014): Chemical composition, antioxidant, antimicrobial and cytotoxic activities of Tagetes minuta and Ocimum basilicum essential oils. Food Sci. Nutri., 2, 146-155.

Vieira, P.R., de Morais, S.M., Bezerra, F.H., Ferreira, P.A.T., Oliveira, Í.R. and Silva, M.G.V. (2014): Chemical composition and antifungal activity of essential oils from Ocimum species. Indust. Crops Products, 55, 267-271. 